\title{
QUALITY DIMENSIONS OF PURCHASE BEHAVIOR DECISION ON FISHERY PRODUCTS
}

\author{
Nurliza*)1, dan Eva Dolorosa*) \\ *) Agribusiness Department, Faculty of Agriculture, University of Tanjungpura \\ Jl. A. Yani, Pontianak 78124
}

\begin{abstract}
The role of fishery product has been developed and acknowledged in terms of food security both as income sources and food supplies for developing countries. On the other hand, quality control has become a challenge in overcoming consumers' decision to purchase the products. The objective of research is to understand and evaluate consumer behavior in purchasing the products in regards to quality dimension on fishery products by using non-probability sampling technique to 142 consumers in three different locations in Pontianak (shops, mini/supermarkets, and local markets). Data were gathered by indepth interviews divided into four categories consisting of consumer profiles; product knowledge; perception and preference; and quality dimension variable with conjoint analysis. The result shows that price, flavor, moistness, texture, nutrition, packaging color, and packaging size do not affect consumers' decision to purchase the products. On the contrary, package durability attribute is the primary factor in their decision to purchase, and it is then followed by packaging material, availability, flavor, guarantee, guarantee source, brand, packaging form, and product form. This is beneficial for producers to improve the quality factors and develop market opportunities in the future. Besides, consumers can obtain information on product characteristics to fulfill their expectation and satisfaction.
\end{abstract}

Keywords: conjoint analysis, fishery products, non-probability sampling, purchase behavior, quality dimensions

\begin{abstract}
ABSTRAK
Peran produk olahan perikanan telah berkembang dan diakui dalam keamanan pangan-baik sebagai sumber pendapatan maupun sumber makanan bagi negaranegara berkembang. Namun, pengendalian terhadap karakteristik mutu menjadi sebuah tantangan dalam menghadapi keputusan pembelian konsumen. Tujuan penelitian adalah memahami dan mengevaluasi perilaku keputusan pembelian konsumen terkait dimensi mutu pada produk olahan perikanan menggunakan teknik non-probability sampling terhadap 142 konsumen pada tiga lokasi di Pontianak (toko, mini/supermarket, dan pasar lokal). Data dikumpulkan dengan metode wawancara mendalam yang terbagi menjadi empat bagian, yaitu profil konsumen; pengetahuan produk; persepsi dan preferensi; dan variabel dimensi mutu dengan conjoint analysis. Hasil menunjukkan bahwa harga, aroma, kelembaban, tekstur, nutrisi, warna kemasan, dan ukuran kemasan tidak memengaruhi keputusan pembelian konsumen. Namun, atribut daya tahan prduk menjadi faktor terpenting dalam keputusan pembelian yang diikuti dengan bahan kemasan, ketersediaan, aroma, jaminan, sumber jaminan, merek, entuk kemasan, dan bentuk produk. Hal tersebut bermanfaat bagi produsen untuk meningkatkan mutu yang dipentingkan oleh konsumen dan mengembangkan peluang pasar dimasa mendatang. Disamping itu, konsumen dapat memperoleh informasi karakteristik produk penting untuk memenuhi kepuasan dan harapan konsumen.
\end{abstract}

Kata kunci: conjoint analysis, produk olahan perikanan, non-probability sampling, perilaku pembelian, dimensi mutu

\footnotetext{
${ }^{1}$ Alamat Korespondensi:

Email: nurliza.spmm@gmail.com
} 


\section{INTRODUCTION}

In the current situation, the role of fishery product has been developing and acknowledged in term of food security either as an income source, as well as food supplies for developing countries. In line with the outcome of the 1996 World Food Summit, relevant strategies need to be in place for the different food sectors, including the fishery products (Westlund, 2005). Over the last few years, there has been a growing recognition that fishery products processed techniques aimed at controlling either the inputs may not be sufficient on their own to adequately address many of the management challenges. In developing markets opportunities, consumers need to have sufficient and reliable information about other essential product characteristics which is rising affluence with higher disposable incomes and associated spending power will thus support greater growth in consumers' demand (Asensio and Montero, 2008).

Nowadays, companies are more concerned on individual consumer behavior which particularly associated with the purchasing behavior. It helps them to yield information about how the consumers think, feel and choose their products because every individual is consumer. The study of consumer behavior provides us with reasons why consumers differ from one another in buying and using products. This receives stimuli from the specifics of products attributes, and responds to these stimuli in terms of either buying or not buying product. In between the stage of receiving the stimuli and responding to it, the consumer goes through the process of making. What is more, the expand view of consumer embrace much more than the study of why and what consumer buy, but also represents the ground for operators to develop appropriate marketing strategies for their products and policy makers to design intervention plans for fishery products operators who are confronted with these progressive changes. At the same time, potential new agents need to acquire information about consumer perception, so as to create a business that can withstand the difficulties that the sector is facing.

While, customers have exposed to different window of information and varieties of products; many great deal of choices and options available in the market place try affect their purchase decision. The interpretation and decision making is still different among individuals and also influenced by internal and external factors.
After reviewing different studies which are concern in purchasing behavior, the own creation of the theoretical framework was formed. It was believed that the framework consists of main attributes that have impact on purchase intention of fishery products is quality. The quality is one among of perceptual, conditional, and somewhat subjective attribute and may be understood differently by different people that influences of internal consumer behavior. The quality has a pragmatic interpretation as the non-inferiority or superiority of something; and defined as fitness for purpose.

Consumer still remains the determinant of the quality which is diversity at market. Consumers may focus on the specification quality of a product, or how it compares to competitors in the marketplace. If consumer tastes and food habits are assessed in advance, i.e. prior to production, variety of products, and marketability then the producer might measure the conformance quality, or degree to which the product was produced correctly to supply them. Understanding consumer for the purpose of achieving marketing objective is imperative to satisfy needs and wants of consumers, or consumers strongly influence what will be produced for whom and what resources will be used to produce it.

In order to develop a framework for consumer and producer that associated with consumer behavior and quality improvement effort, it is helpful to begin by considering the intentional selecting fishery products and purchasing decision. While the challenges are exacerbated by unsustainable dietary patterns-both under and overconsumption that in differing ways affect markets, health and the natural resource base. Current fisheries products consumption trends and how these consumption trends impact the ability of producer for quality improvent to provide food for all are addressed in this section.

The objective of this research is to achieve a better understanding and to evaluate the purchase behavior of consumer decisions that associated with quality dimensions of processed fishery products that intent to influence consumers' processes which is typically based on the general perception in evaluating the product. Furthermore consumer and buyer behavior is in fact an ongoing process, not merely indicates the interaction between consumers and producers at the time of purchase but it made beneficial for producers to identify and to evaluate the quality attributes for quality 
improvement and to develop market opportunities in the future. In addition, consumers can obtain essential information of product to meet consumer satisfaction and expectations.

\section{METHODS}

Quantitative data for the first study were collected through a cross-sectional consumer survey since April - May 2015 in Pontianak which was conducted among 142 consumers through non-probability sampling at three different types of places in Pontianak (shop, mini/supermarket, and local market). This size is meet the requrement in the minimum sample in multivariate analysis to estimate the indicators as the research property (Hair et.al., 1992; Fraenkel \& Wallen, 1993; Sugiyono, 2003).

The framework for this research was analyzed with multivariate technique that arises from more than one variable through conjoint analysis. It was built in order to achieve a better understanding and to evaluate the quality dimensions of processed fishery products that intent to influence consumers' processes. The conjoint analysis is the optimal market research approach for measuring the value that consumers place on features of a product with the modeling of actual market decisions. Thus, data collection was conducted through deepinterviews, which gathered information effectively as the number of incomplete questionnaires is minimised. The questionnaire divided into four sections, chosen on the basis of a literature review which correspond to the sections of the questionnaire.

First, interviewee profile: the first section includes questions concerning the main socioeconomic characteristics of respondents which was representative for region and covers a wide range of socio-demographics, i.e. gender, age, educational qualification, head of the family occupation, and family member. As recommended by Gunter and Furnham (1992) general demographic variables were included in the questionnaire. The occupation of the head of household was considered to evaluate family income level; the method is still generally used, though not generally accepted in econometrics (Frank et.al., 1972). Second, Sample knowledge of poduct: these questions concern of the types knowledge in terms of salted fish, dried fish, fish cackers, and terasi which is commonly produced in West Kalimantan.
Third, Perception and preference: we analyse consumer evaluation of fishery products attributes in relation to product purchase. The study starts from two analyses conducted at European (Verbeke and Brunso, 2006) levels. The customers were asked about frequency of buying them-representing product-specific variables already used by Wedel and Kamakura (2000). Our survey investigates this conflicting behavior. Thus, consumers were asked if they consider purcahasing product the best in terms of frequency, place, the motivation, and processed food from the product.

Fourth, Variables of quality dimensions: the last section assesses the customers level of consideration of quality such as price, product form, odor, flavor, moistness, texture, self-life, process of production, nutrition, form of packaging, color of packaging, packaging size, material of packaging, availability, brand, source of quarantee, and the quarantee of product. Interviewees expressed their opinion through Likert scales. Nominal variables have been equally labelled with progressive numbers. In recent years, researchers have chosen conjoint analysis which is based on the stated preference approach by observing consumer responses to different alternatives to estimate preferences for each attribute of the product, including the reduction of some of the potential biases, more information from each respondent, the possibility of testing for internal consistency (Orme, 2010; Alpizar et.al., 2003). While, SPSS version 19.0 is used for conjoint analysis as multivarate analysis to identify and to evaluate the quality attributes of consumer's preference that was significant influence the pushase decisions.

\section{RESULTS}

\section{Socioeconomic Characteristics of the Sample}

The information on socio-demographic profile of the consumers collected were gender, age, educational qualification, head of the family occupation, and family member. We did 142 interviews on three sites: in a fishery product shop (23.94\%), at a local market (67.61\%), and at mini/supermarket (8.45\%) (Table 1). It confirms that local market is the most preferred. The socio-demographic profile information confirms that purchasing pattern of fishery products from the local market is preferred which is also proved by Wongleedee (2015) and revealed a significant correlation between the consumers' attitudes towards place and buying behavior in terms of the buying frequency. 
Considering gender, most respondents are female consumers on these three sites $(81.69 \%)$ and small part of male respondents $(18.31 \%)$. This result is confirmed by Mugaonkar et al. (2011) that generally women play an important role in purchasing of fishery products for domestic consumption at local market. Webster and Reiss (2001) also proved that the changes in the perception of the role of women may alter the influence of each spouse on the purchase of products that were locally associated with a particular sex and they can also affect conflict-resolution tactics. Therefore, an unmistakable tendency towards joint decisions in the couple, with women playing the specialized role of grocery buyer or grocery is still the realm of women and it will continue to grow in line with (IIPS, 2015; Barlés-Arizón et al. 2013). This is why it is important for companies to create a business strategy that includes marketing to women-creating a marketing plan that focuses on the female consumer. Among the total female respondents, majority of the consumers are used to buy at local market $(78,67.24 \%)$, followed by fishery product shop $(28,24.14 \%)$, and mini/ supermarket $(10,0.09 \%)$. However, a larger proportion of male consumers can be, to certain extent, attributed to greater unwillingness among female consumers in taking part in the survey.

Regarding age, $33.1 \%$ of the respondents in the main age group of 41-50 years, followed by the $31-40$ years group (28.87\%), until 30 years $(23.24 \%), 51-60$ years group (11.27\%), and $61-70$ years group $(0.04 \%)$. It was found that more than half of the main age group of 4150 years consumers $(55.32 \%)$ bought at local market, followed by fishery product shop (34.04\%), and mini/ supemarket $(10.63 \%)$. This revealed that people under the age of 50 years $(52.11 \%)$ constituted the biggest segment of purchasing consumers, while until 30 years age and old customers (more than 50 years) seem to prefer buying in shops or mini/supermarkets. This result in line with Verma and Upadhyaya (2014) that the factors leading to preference towards the local grocery stores of respondents who were of the age of 40 and above, were not affected much of product assortment, consumer ease and consumer services when it comes to choosing local grocery stores for their purchase. In other words, as the age of the respondents increase, they are not influenced by the attributes of these dimensions and hence prefer to buy their groceries from the local grocery stores. It might be because they have been dealing with the same store and have developed long term relationship with it. While, there was a link of age with the product assortment, consumer ease of getting product and consumer service factors to preference towards the local grocery stores of respondents below the age of 40 got affected for the product. In educational qualification, it seems that there is no significant influence on the consumption of fishery products.

This result is confirmed by some studies that sociodemographic and personality indicators have had only limited success in profiling consumers according to their pro-environmental purchasing behavior, e.g. Thomson and Kidwell (1998) stated that age, gender, and having a college degree just had little impact on a shopper's decision to buy food product. Mutsikiwa and Basera (2012) also proved that although sociocultural variables play a significant role on individual's perception and consumption, they are not key determinants in influencing the individual consumer.

Meanwhile, on educational qualification, half of the respondents have a senior high school (50\%), followed by degree $(46.48 \%)$, junior high school $(0.03 \%)$, and elementary school $(0.01 \%)$. Most consumers of senior high school bought at local market $(81.9 \%)$, while $12.68 \%$ at fishery product shop, and $0.06 \%$ at mini/ supemarket.

While, information on the head of the familiy occupation was collected in terms of self-employed, manager white-collar, blue-collar, pensioner and housewife/ unemployed. It was found that $42.25 \%$ of respondents as a white-collar, $23.24 \%$ as s self-employed, $21.13 \%$ as a blue-collar, $0.08 \%$ as a pensioner, a manager, and housewife/unemployed. It was found that more than half of white-collar consumer bought at local market $(60 \%)$, while $28.33 \%$ at fishery product shop, and $11.67 \%$ at mini/supemarket. Then, it was found that a white-collar respondents more than others head of the familiy occupation. It seems to be no correlation was found between head of family occupation and shop type. Looking at the local market, white collar customers bought more than those purchasing at fishery shop or mini/supermarket. In this case, the data depict families with less or more purchasing power compared with the modern distribution (shop or mini/super market) sample did not involve a clear description of customer behavior. For the rest, fishery products shop and mini/ supermarket buyers appeared similarly distributed in the whole local market channel sample. 
Table 1. Socio-demographic characteristics

\begin{tabular}{|c|c|c|c|c|c|c|c|c|}
\hline \multirow[t]{2}{*}{ Variables } & \multicolumn{2}{|c|}{ Local market } & \multicolumn{2}{|c|}{ Fishery product shop } & \multicolumn{2}{|c|}{ Mini/ supermarket } & \multicolumn{2}{|c|}{ Total Frec. } \\
\hline & Freq. & $\%$ & Freq. & $\%$ & Freq. & $\%$ & Freq. & $\%$ \\
\hline \multicolumn{9}{|l|}{ Gender } \\
\hline Female & 78 & 81.25 & 28 & 82.35 & 10 & 83.33 & 116 & 81,69 \\
\hline Male & 18 & 18.75 & 6 & 17.65 & 2 & 16.67 & 26 & 18,31 \\
\hline \multicolumn{9}{|l|}{ Age } \\
\hline until 30 years & 27 & 28.13 & 4 & 11.76 & 2 & 16.67 & 33 & 23,24 \\
\hline $31-40$ years & 31 & 32.29 & 8 & 23.53 & 2 & 16.67 & 41 & 28,87 \\
\hline $41-50$ years & 26 & 27.08 & 16 & 47.06 & 5 & 41.67 & 47 & 33,10 \\
\hline $51-60$ years & 9 & 9.38 & 5 & 14.71 & 2 & 16.67 & 16 & 11,27 \\
\hline $61-70$ years & 3 & 3.13 & 1 & 2.94 & 1 & 8.33 & 5 & 3,52 \\
\hline more than 70 years & - & - & - & - & - & - & - & - \\
\hline \multicolumn{9}{|l|}{ Educational } \\
\hline Elementary school & 1 & 1.04 & - & - & - & - & 1 & 0,70 \\
\hline Junior school & 3 & 3.13 & 1 & 2.94 & - & - & 4 & 2,82 \\
\hline Senior School & 58 & 60.42 & 9 & 26.47 & 4 & 33.33 & 71 & 50,00 \\
\hline Degree & 34 & 35.42 & 24 & 70.59 & 8 & 66.67 & 66 & 46,48 \\
\hline \multicolumn{9}{|c|}{ Head of the familiy occupation } \\
\hline Self-employed & 26 & 27.08 & 6 & 17.65 & 1 & 8.33 & 33 & 23,24 \\
\hline Manager & 1 & 1.04 & 2 & 5.88 & 2 & 16.67 & 5 & 3,52 \\
\hline White-collar & 36 & 37.50 & 17 & 50.00 & 7 & 58.33 & 60 & 42,25 \\
\hline Blue-collar & 26 & 27.08 & 3 & 8.82 & 1 & 8.33 & 30 & 21,13 \\
\hline Pensioner & 5 & 5.21 & 5 & 14.71 & 1 & 8.33 & 11 & 7,75 \\
\hline Housewife/unemployed & 2 & 2.08 & 1 & 2.94 & - & - & 3 & 2,11 \\
\hline \multicolumn{9}{|l|}{ Family member } \\
\hline 1 & 15 & 15.63 & 3 & 8.82 & 2 & 16.67 & 20 & 14,08 \\
\hline 2 & 22 & 22.92 & 8 & 23.53 & 2 & 16.67 & 32 & 22,54 \\
\hline 3 & 33 & 34.38 & 15 & 44.12 & 7 & 58.33 & 55 & 38,73 \\
\hline 4 & 18 & 18.75 & 5 & 14.71 & 1 & 8.33 & 24 & 16,90 \\
\hline 5 & 5 & 5.21 & 3 & 8.82 & - & - & 8 & 5,63 \\
\hline 6 & 3 & 3.13 & - & - & - & - & 3 & 2,11 \\
\hline \multicolumn{9}{|l|}{ Purchase frequency } \\
\hline Never & - & - & 31 & 91.18 & - & - & 31 & 21,83 \\
\hline Periodically & 90 & 93.75 & 2 & 5.88 & 10 & 83.33 & 102 & 71,83 \\
\hline Monthly & 5 & 5.21 & 1 & 2.94 & 2 & 16.67 & 8 & 5,63 \\
\hline Weekly & 1 & 1.04 & - & - & - & - & 1 & 0,70 \\
\hline Twice weekly & - & - & - & - & - & - & - & - \\
\hline Total & 96 & 67.61 & 34 & 23.94 & 12 & 8.45 & 142 & \\
\hline
\end{tabular}

The last information is family member, 3 of family members are the mostly consumers $(38.73 \%)$, followed by $2,4,1,5$, and 6 . Mostly consumers with 3 of family member bought at local market (60\%), while $27.27 \%$ at fishery product shop, and $12.73 \%$ at mini/supemarket. This result indicated that buyer behavior is strongly influenced by the family member and effective primary reference group, particularly from older children which is confirmed by Solomon (2006) that young children are more concern for healthy foods and fruits while single households or those with older children are likely to use more junk foods.

In frequency of purchase, most of respondents bought on periodically. Wongleedee (2015) stated that the consumers' higher frequency level of purchasing goods at local market determined the likelihood of future purchasing, revisiting to shop at the local market, recommending others and more frequent shopping in case of receiving higher income. This agreed with 
many previous studies which reported a significant relationship between the frequency of purchasing and the likelihood of regular visits to shop at local market in the future and of recommending others to do so. Finally, in that the more money consumers spent shopping at the market, the more frequent the visits and the more spending if there would be an increase in income.

\section{Product Knowledge of Respondents}

Consumer's knowledge was frequently different from real product knowledge. The aim of this part of the survey is to reveal customers possibly evaluating mistakes and prejudices on fishery products purchasing. Obviously, the more it is known, the more they are disposed to buy it. Respondents proved to have a good of knowledge or have seen them, such as salted fish, dried fish, fish crackers, terasi (more than $90 \%$ of samples), so then can differentiate among products in the bench and now fully established as part of consumer habits.

Laroche et al. (2003) and Baker et al. (2002) confirmed that consumers behave differently when buying inexpensive products and expensive products, everyday products and services which intent to use in the long-term. Consumers who have a high level of product involvement may also purchase counterfeits willingly. The results of this study provide no support to the proposition that product knowledge influences purchase intention, but partial support to the proposed relationship between product knowledge and perceptions. It has been recognized as a characteristic in consumer research that influences all phases in the decision process. Consumers with various levels of product knowledge differ in their perceptions of product attributes. Thus, consumers' with higher levels of product knowledge have better developed and more complex schemata, with well-formulated decision criteria. Therefore, the higher the level of product knowledge a consumer possesses, the less chance there is that he/she will generate evaluation bias.

\section{Perception and Preference}

This section of the questionnaire touched upon a set of product attributes that can influence consumers' perception and preference. Thus, consumers were asked if they consider purchasing product the best in terms of frequency, place, the motivation, and processed food from the product. Considering the knowledge, majority of the respondents $(71.83 \%)$ admited that frequency of buying is periodically, and maximum of among them $(88.24 \%)$ stated that the purchasing is done at local market, followed by mini/supermarket and fishery product shop. It seemed to be realized in local markets. They agreed with the general opinion that their cost less than except for those in modern markets, and provide more product options. However, the qualities still are not fully guaranteed and there are problems in characteristics of quality, e.g. quality standard due to season.

Consumers' perception seemed partly tied to preconceived notions due to possibly inadequate information reaching the consumers' and certain behavior which is reflecting "psychological" of customers, e.g. fishery products as inferior product, low quality (odor, appearance, packaging, mostly not guaranteed, the food safety is not guarantee), and as complementary food and easily processed. In fact, mostly of the sample respondents declared to be sensitive to any fishery products preparation, whereas mostly strongly wanted to be a 'cleaned' product.

\section{Quality Dimensions}

There are nineteen attributes of quality dimensions, i.e. price, product form, odor, flavor, moistness, texture, self-life, process of production, nutrition, form of packaging, color of packaging, packaging size, material of packaging, availability, brand, source of quarantee, and the quarantee of product which are used to analyze the consumer's behavior in purhasing decision. It was found that eight attributes (product form, odor, self-life, form of packaging, material of packaging, availability of product, brand, quarantee of product, and source of quarantee) are mostly (91\%) significant influence consumers' preference at three types of market. While price, flavor, moistness, texture, nutrition, color of packaging, packaging size has not proven to have significant influence. The study revealed that quality dimensions, e.g. self-life was the most important (Figure 1), followed by material of packaging, the availability, odor, the guarantee, the source, brand, form of packaging, and the form of product.

This study proved that the price was not influence on the choice of respondents and they affirmed that price as "non fundamental" to "irrelevant" because of their purchase was occasionally happend. This result is also confirmed by Brijball (2003) and Zeithaml (1988) that quality followed by price is important general evaluative 
criteria, but their importance diminishes when other product attributes are included-only a quarter of the subjects perceive price and quality as having a one to one relationship. While, it is presumed that consumers would conduct a search for information prior to their purchase, research suggests that consumers use only a small amount of the information available to make a decision (Lockshin et al. 2000; Foxall, 1983).

In Figure 2, the shelf-life most preferred by consumers is one day to two weeks; surprisingly, consumers don't like one month to more than six months. Thus, due to consumer perception that a long shelf-life of product represent product quality has been reduced. Also, consumer preferences are influenced by the availability of fishery products.

This research revealed that self-life of product was the most important quality dimensions factors among the others for guiding purchasing behavior because consumers' expectation in terms of food safety. Thus, Köse (2010) underline the importance of food safety and still wide acceptance around the world particularly in developing countries due to their accustomed flavor and odor. The shelf-life is associated with materials of packaging which is safe for food consumption and intensify the durability of the product. Mostly, consumers really did not appreciate a long shelf-life time of product due to consumer perception of quality decrease.

It also revealed that mostly respondents ranked the parameters of odor with savory or salted of odor. Conversely, consumer did not prefer sweet or bargain odor due to the perception of mostly odor. Mugaonkar et al. (2011) findings that as fish munch is the extruded product, the crispiness and the size of piece are the two very important features get along with product name and packaging. As per the sensory evaluation, it was found that there was scope for improvement in the odor and appearance to face the existing market competition.

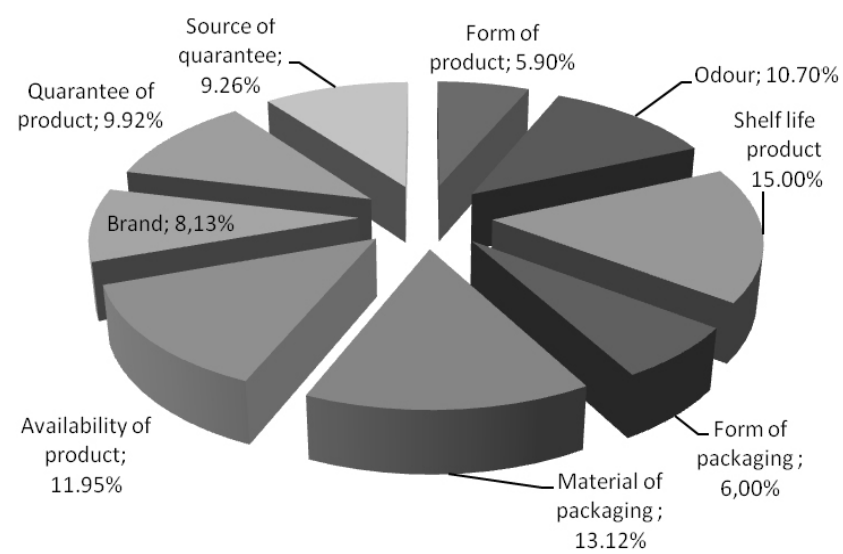

Figure 1. Contribution of quality dimensions in consumers' purchase behavior

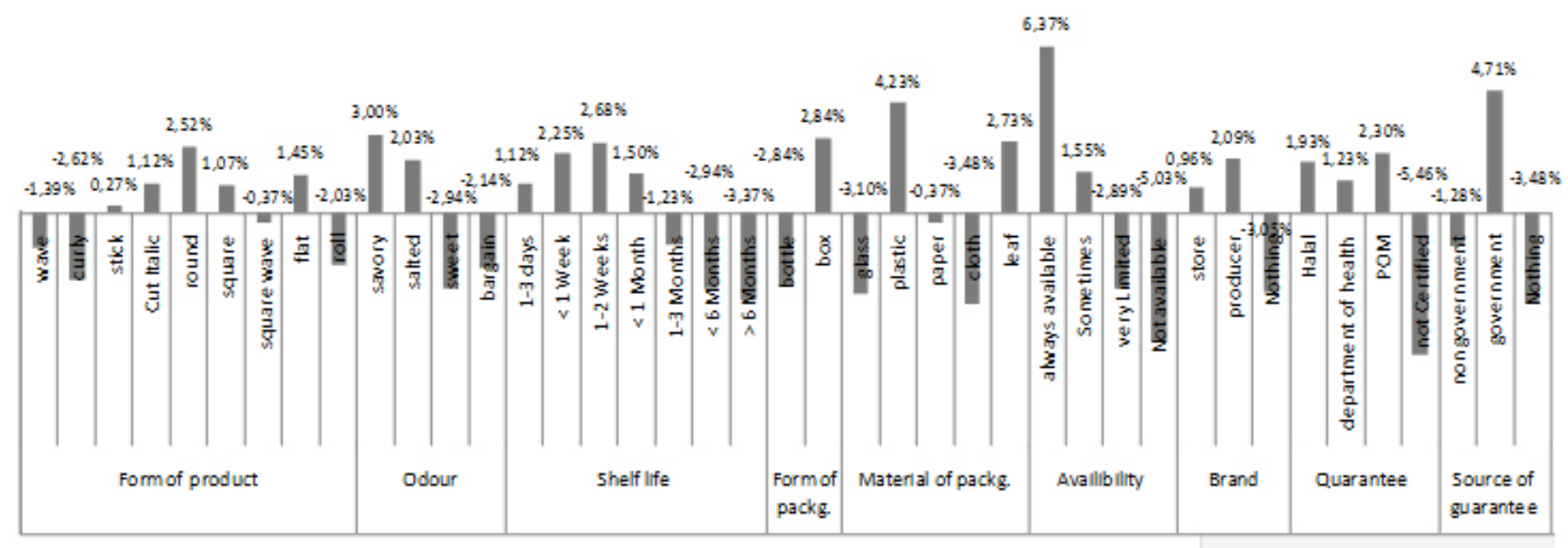

Figure 2. Contribution of specific quality dimensions atributes 
The sensory evaluation of packaging revealed that there was low quality of packaging and most respondent shown that their dissatisfaction over it. Many respondents desired improvement in this feature for more acceptable. Material and form of packaging should be taken into consideration. Poor appearance reflected on the price negatively. The results confirmed that consumers' mostly preferred by plastic material for packaging (Figure 2). Material of packaging from leaf is selected for terasi. Box shape is more preferred, conversely with bottle shape.

The impact of package elements on consumers purchase decisions has been evaluated, and it is concluded that it depends on the consumer's involvement level, time pressure or individual characteristics. Some studies have found that different packaging cues impact and how a product is perceived. It is concluded that most consumers like the product quality after they purchased their desired packaged product (Ahmed et al. 2014). According to Smith and Taylor (2004) consumers link the packaging materials with certain essential values of the product which could change the perceived quality of a product. Innovative packaging, the quality of the packaging material and practicality can attract consumers and add the value to meet consumer needs and desire, e.g. easily opened and stored, recyclable, etc on product selection during buying process. Silayoi and Speece (2007) corroborated the findings that visual elements on packages positively influenced purchase decisions more than informational elements as far as low involvement purchase situation was considered in line with Venter et al. (2011) that participants mainly perceived food packaging based on its functional and physical attributes through unprompted awareness. It was also clear that appearance attributes played a key role in attracting the attention of participants. Participants interpreted the visual stimuli communicated to them through the packaging in the final step of the perceptual process, namely comprehension. Negative associations with packaging mostly entailed associations with poor quality in the case of certain types of packaging.

However, there was contradiction, Shekhar and T. (2013) and Estiri et al. (2010) confirmed that informational elements on packaging were considered as more important in purchase decisions than visual elements. Zekiri (2015) also stated that the information on packaging can support marketing communication, establishes brand image, and identity. In this regard, information attributes of packaging were crucial for deciding whether to choose the product. Smith and Taylor (2004) stated that materials also affect the perceived quality of a product. Some packaging materials are to be made in a way, depending on the product functionalities and the needs of a consumer. This study revealed that mostly consumers prefer plastic material of packaging which is supported by Hollywood et al. (2013) that such containers were better than cardboard and glass packaging because their screw top cap prevented the product and were less likely to leak.

The other sensory evaluation revealed that mostly respondents were more satisfied with savory or salted of odor, and conversely, consumer did not prefer sweet or bargain odor due to the perception of mostly fishery products odor. It can be perceived that an opportunity to improve the odor, taste and appearance of the product. Another consumer preference atribut is quarantee. Quarantees and quarantee sources are stipulated in the Government Regulation No. 28 of year 2004 on Safety, Quality, and Nutrition for the standard of food safety requirements and conditions that must be accomplish to prevent food from possible danger, either because of biological, chemical and other substances that can disrupt, and harm for human health. Both of these hazards have to be measured and controlled in order to increase the safety of the food supply. Product and source of guarantee feature are reflecting in the product label; label both as a part of the food package. The label on-shelf must contain necessary, accessible and understandable information and be located in a visible and clear way to consumers. Thus, mostly consumers are very concerned with food safety and halal certificate, also recognation from department of health and Food and Drugs Control Department from government institution, not the others quarantee.

This finding in line with Caswel (2006) and Wandel (1997) that consumers have general positive attitudes towards food labels. Food labels are one of the most used and trusted sources of information (Wills et al. 2009). Thus, consumers are very concerned with halal certificate, also recognation from department of health and Food and Drugs Control Department from government institution. This concern is in line with some empirical studies in some country or region that despite the preserving aim of such local methods, these products are still under risk of several hazards (Köse, 2010) and reported to carry high potential risk for human 
health for halophilic pathogenic bacteria, histamine and parasites (Tsai et al. 2006; Huss et al. 2003; Karaçam et al., 2002; Kuda et al. 2002; Mah et al. 2002; Lehane and Olley, 2000; FDA, 2001; Kirschbaum et al. 2000; Essuman, 1992) and a significant body of scientific literature documents that consumers nowadays are more interested in healthy food products to prevent diseases and maintain healthy living (Krutulyte, 2010).

Verbeke and Ward (2006) reported that consumers are selective in the attention they pay to different label cues. The most attended label cues were those that helped consumers to readily infer product quality, e.g. expiry date and type of product. Labeling helps consumers spend less time needed while searching for products that are decided to be bought by them, it confirmed by Shah et al. (2013) that labeling is one of the most visible parts of product and an important element of the marketing mix. Consumers under time pressure their decisions are influenced when the package comes with a distinctive appearance that contains simple and accurate information (Silayoi and Speece, 2004).

However, the consensus from these studies is that label information usage and consumer awareness of label information cannot be taken for granted, though depends on the food, situation and person considered (Pieniak, et al. 2011). The consumers' value label may often be of little use, because lack of knowledge at the consumer level and inability to perform simple inference-making leads to failure in decoding simply understanding the information, but information about its origin, its content, its usage, etc, will help companies promote the product in the market (Zekiri, 2015; Grunert, 2005).

The next attribute is the brand. A few of them have created their brand from a reputable institution that recognized by government or consumers. Most of the product only had guarantee from producers or stores. It was attested that $70.42 \%$ of the respondents accorded higher emphasis to branded product, while $29.58 \%$ of the respondents gave less importance to brand name. Thus, the respondents were highly health conscious and insisted on the brand of products. The brand will show how the product will be perceived and become quality guarantee or food safety. Products with high quality mostly have a good brand too.

The brand image refers to the framing of memory about a brand, which contains the results of interpretation by consumer to the messages, attributes, benefits, and advantages of the product (Wijaya, 2013) and has a significant influence on purchase intention (Santoso \& Najib, 2015). The brand image represents what consumers think and feel about a brand identity. Thus, the image of a brand represents the perception that can reflect objective or subjective reality. An image can create value to consumers by helping to process information; differentiate their preferred brands, facilitating buying, giving positive feelings, and providing a basis for product extensions (Aaker, 1991). Lockshin et al. (2000) highlights the fact that brand name acts a surrogate for a number of attributes including quality and acts as a short cut, in dealing with risk and providing product cues. Jobber and Fahy (2003) state that there are three brand strategies can be identified: family brand name (also known as umbrella branding), individual brand name, and combination brand name. The family brand name indicates the brand name is used for all products, whereas individual brand name does not identify a brand with a particular company.

In the form of product attributes, consumers preferred some forms, e.g. stick, cut italic, round, flat, and square. While some form undesirable, e.g. wave, curly, square wave, and roll. Thus, the enterprises may consider this as an opportunity for generating awareness among the consumers about their diversified products to diversify their products with the appropriate marketing strategy. Many studies also proved that the form of product effects consumers preference (Lian and Lin, 2008; Liao and Cheung, 2001). Keisidou et al. (2011) made it clear that the product classification and type of products that were selected are responsible for the variations in the results in the present study.

\section{Managerial Implication}

The managerial implication of this research is developed in order to achieve a better understanding and to evaluate the purchase behavior of consumer decisions that associated with quality dimensions of processed fishery products that intent to influence consumers' processes. This research also provides some evidence that socio-demographic profile of buyers tends to have significant influences on consumer perceptions of choosing a product. 


\section{CONCLUSIONS AND RECOMMENDATIONS}

\section{Conclusions}

It's confirmed that a significant correlation between the consumers' attitudes towards place-the local market. Females play an important role and the changes in woman's perception may alter the influence of each spouse on the purchase of products. While leading factors to preference towards the local market that were of the age group of 41-50 years because they have been dealing with the same store and have developed long term relationship. This contradicts what has taken place in below the age of 40 that was a link to age with the product assortment, consumer ease, and consumer service to consumer's preference. It is shown by senior high school and white-collar that just had more impact on consumer's decision. Considering family member, 3 of family members are the mostly consumers' because this behavior was strongly influenced by the family member and effective primary reference group, particularly from older children. Then, it was found that the consumers' higher frequency level of purchasing goods at local market determined the likelihood of future purchasing, revisiting to shop at the local market, recommending others and more frequent shopping in case of receiving a higher income.

This research revealed that seven attributes (price, flavor, moistness, texture, nutrition, color of packaging, packaging size) are not statistically significant the purchase behavior of consumer decisions. The result for the price that does not influence the choice of respondents affirmed price as "nonfundamental" to "irrelevant" because they did not buy it in regularly. However, the study revealed that quality dimensions, e.g. Self-life were the most important, followed by material of packaging, the availability, odor, the guarantee, source of guarantee, brand, form of packaging, and the form of product. For customer's satisfaction and needs, this study also revealed that self-life of product was the most important factors for guiding purchasing behavior because consumers' expectation in terms of food and still wide acceptance around the world particularly in developing countries due to their accustomed flavor and odor. Consumer preferences are also influenced by the availability of product. Meanwhile, packaging of the product was poor and mostly respondents showed their dissatisfaction over it. Material and form of packaging should be taken into consideration for further improvement. Box shape is more preferred, conversely with bottle shape. Product and source of guarantee feature are reflecting in the product label. The label on-shelf must contain necessary, accessible and understandable information and be located in a visible and clear way to consumers. Consumer's also accorded higher emphasis to branded product that was insisted on it. In the form of product attribute, consumers preferred some forms, e.g. stick, cut italic, round, flat, and square. While some form undesirable, e.g. wave, curly, square wave, and roll.

\section{Recommendations}

The gender of buyers tends to have influences on consumer perceptions and females play an important role. This is why it is important for companies to create a business strategy that includes marketing to women. It also suggested that local market could becomes a place in the place strategy to attract consumers. The price was "nonfundamental" to "irrelevant" factor and therefore, producers can use non-price strategies for marketing of local fisheries products and quality improvement for those attributes. Moreover, the knowledge at the consumer level and the ability to perform simple inference-making leads to success in decoding simply understanding about its origin, its content, its usage, etc, will help companies promote the product in the market. Consumer's also accorded higher emphasis to branded product and preferred some forms of products. Thus, the enterprises may consider this as an opportunity for generating awareness among the consumers about their diversified products to diversify their products with the appropriate product strategy.

\section{ACKNOWLEDGEMENT}

We would like to express the sincere gratitude to Sambas government district for funding this research. We are grateful to Faculty of Agriculture, University of Tanjungpura for all support that enabled us to do this research. Special thanks to the peer reviewer and the editorial board for their helpful comments, and suggestions of this manuscript.

\section{REFERENCES}

Aaker DA. 1991. Managing Brand Equity. New York: The Free Press.

Ahmed RR, Parmar V, Amin MA. 2014. The impact of product packaging on consumer's buying 
behavior. European Journal of Scientific Research 122(2): 125-134.

Alpizar F, Carlsson F, Martinsson P. 2003. Using choice experiments for non-market valuation. Economic Issues 8(1):83-110.

Asensio L, Montero A. 2008. Analysis of fresh fish labeling in Spanish fish retail shops. Food Control19(8):795-799.https://doi.org/10.1016/j. foodcont.2007.08.005.

Baker T, Hunt JB, Scribner LL. 2002. The effect of introducing a new brand on consumer perception of current band similarity: the role of product knowledge and involvement. Journal of Marketing Theory and Practice 10(4): 45-57. https://doi.org/10.1080/10696679.2002.115019 25.

Barlés-Arizón MJ, Fraj-Andrés E, Martínez-Salinas E. 2013. Purchase decision-making in couple. Conflict-solving tactics. International Journal of Business and Social Science 4(6): 28-43.

Brijball S. 2003. The level of importance attached to price and quality in purchasing behavior. Journal of Industrial Psychology 29(1):93-99. https:// doi.org/10.4102/sajip.v29i1.91.

Caswel JA. 2006. Quality assurance, information tracking, and consumer labeling. Marine Pollution Bulletin 53(10-12): 650-656. https:// doi.org/10.1016/j.marpolbul.2006.08.007.

Essuman KM. 1992. Fermented fish in Africa: a study on processing, marketing and consumption. FAO Fisheries Technical Paper No. 329. Fishery Industries Div. Rome, Italy: FAO.

Estiri M, Hasangholipour T, Yazdani H, Nejad HJ, Rayej H. 2010. Food products consumer behaviors: role of packaging elements. Journal of Applied Sciences 10(7), 535-543. https://doi. org/10.3923/jas.2010.535.543.

FDA. 2011. Fish and Fisheries Products Hazards and Controls Guidance. 4th Edition. Washington, DCC, USA: Food and Drug Administration Center for Food Safety and Applied Nutrition.

Foxall G. 1983. Consumer Choice. London: MacMillan. https://doi.org/10.1007/978-1-349-17089-0.

Frank RE, Massy WF, Wind Y. 1972. Market Segmentation. Englewood Cliffs: Prentice-Hall.

Fraenkel J, Wallen N. 1993. How to Design and Evaluate Research in Education, Second Edition. New York: McGraw.

Grunert KG. 2005. Food quality and safety: consumer perception and demand. European Review of Agricultural Economics 32(3): 369-391. https:// doi.org/10.1093/eurrag/jbi011.

Gunter B, Furnham A. 1992. Consumer Profiles: An Introduction to Psychographics. London: Routledge.

Hair JF, Anderson RE, Tatham RL, Black WC. 1992. Multivariate Data Analysis with Readings, Third Edition. New York: Macmillan.

Hollywood L, Wells L, Armstrong G, Farley H. 2013. Thinking outside the carton: attitudes towards milk packaging. British Food Journal 115(6): 899-912. https://doi.org/10.1108/BFJ-Jul-20100127.

Huss HH, Ababouch L, Gram L. 2003. Assessment and management of seafood safety and quality. FAO Fisheries Technical Paper No. 444. Rome, Italy: FAO.

IIPS D. 2015. An analytical study of consumer's buying behavior: with special reference to female student Astha Joshi. International Journal of Management and Social Science 91-99.

Jobber D, Fahy J. 2003. Foundation of Marketing. Maidenhead. Berkshire: McGraw-Hill.

Karaçam H, Kutlu S, Köse S. 2002. Effect of salt concentrations and temperature on the quality and shelf-life of brined anchovies. International Journal of Food Science and Technology 37:19-28.https://doi.org/10.1046/j.13652621.2002.00526.x.

Keisidou E, Sarigiannidis L, Maditinos D. 2011. Consumer characteristics and their effect on accepting online. International Journal of Business Science and Applied Management 6(2): 31-51.

Kirschbaum J, Rebscher K, Brückner H. 2000. Liquid chromatographic determination of biogenic amines in fermented foods after derivatization with 3,5-dinitrobenzoyl chloride. J Chromatogr A. 881(1-2):517-530. https://doi.org/10.1016/ S0021-9673(00)00257-0.

Köse S. 2010. Evaluation of seafood safety health hazards for local fish products: preventive measure and monitoring issues. Turkish Journal of Fisheries and Aquatic Science 10:139-160.

Krutulyte R. 2010. Functional food acceptance in the food chain. In [thesis]. Denmark: MAPP. Department of Marketing and Statistics. Aarhus School of Business.

Kuda T, Okamoto K, Yano Y. 2002. Population of halophilic bacteria in salted fish products made in the Loochoo Island, Okinawa and the Noto 
Peninsula, Ishikawa, Japan. Fisheries Science 68:1265-1273. https://doi.org/10.1046/j.14442906.2002.00564.x.

Laroche M, Bergeron J, Goutaland C. 2003. How intangibility affects perceive risk: the moderating role of knowledge and involvement. Journal of Service Marketing 17(2): 122-140. https://doi. org/10.1108/08876040310467907.

Lian J, Lin T. 2008. Effects of consumer characteristics on their acceptance of online shopping: Comparisons among different product types. Computers in Human Behavior 24: 48 - 65. https://doi.org/10.1016/j.chb.2007.01.002.

Liao, Ziqi and Cheung, Michael Tow. 2001. Internetbased e-shopping and consumer attitudes: an empirical study. Information \& Management 38: 299-306. https://doi.org/10.1016/S03787206(00)00072-0.

Lehane L, Olley J. 2000. Histamine (Scombroid) fish poisoning. A review in a risk-assessment framework. National Office of Animal and Plant Health Canberra. Australia: Agricultural, Fisheries and Forestry of Australia.

Lockshin L, Rasmussen M, Cleary F. 2000. The nature and roles of a wine brand. Australia and New Zealand Wine Industry Journal 15(4): 17-24.

Mah JH, Han HK, Oh YJ, Kim MG, hwang HJ. 2002. Biogenic amines in Jeotkals, Korean salted and fermented fish products. Food Chemistry 79: 239-243. https://doi.org/10.1016/S03088146(02)00150-4.

Mugaonkar PH, Ananthan PS, Samal SS, Debnath B. 2011. A study on consumer behaviour at organized fish retail outlet. Agricultural Economics Ressearch Review 24: 133-140.

Mutsikiwa M, Basera CH. 2012. The influence of sociocultural variables on cnosumer's perception of halal food products: a case of Masvingo urban, Zimbabwe. International Journal of Business and Management 7(20): 65-75.https://doi. org/10.5539/ijbm.v7n20p112.

Orme B. 2010. Getting Started with Conjoint Analysis: Strategies for Product Design and Pricing Research. 2nd Edition. Madison: Research Publisher LLC.

Pieniak Z et al. 2011. Consumption patterns and labelling of fish and fishery products in Poland after crisis. Food Control 22: 843-850. https:// doi.org/10.1016/j.foodcont.2010.09.022.

Santoso D, Najib M. 2015. Brand Equity Susu Cair UHT dan Pengaruhnya pada Puchase Intension.
Jurnal Manajemen \& Agribisnis 12(1): 46-56. https://doi.org/10.17358/JMA.12.1.46.

Shah, S., et.al. (2013). Role packaging in consumer buying behaviour. International Review on Basic and Applied Science 1(2): 35-41.

Shekhar SK., T RP. 2013. Role of packaging cues on consumer buying behaviour. International Journal of Engineering and Management Sciences 4(1): 61-69.

Silayoi P, Speece M. 2004. Packaging and purchase decisions: a focus group study on the impact of involvement level and time pressure. British Food Journal 106(8): 607-28. https://doi. org/10.1108/00070700410553602.

Silayoi P, Speece M. 2007. The importance of packaging attributes: a conjoint analysis approach. European Journal of marketing 4(11):1495-1517.https:// doi.org/10.1108/03090560710821279.

Smith PR, Taylor J. 2004. Packaging in Marketing Communication. London: Kogan Page Limited.

Solomon MR. 2006. Consumer Behavior. 7th Edition. London: Pearson.

Sugiyono. 2003. Metode Penelitian Bisnis. Bandung: Alfabeta.

Thomson GD, Kidwell J. 1998. Explaining the choice of organic produce, cosmetic defects, prices, and consumer preferences. American Journal of Agricultural Economics 80(2): 277-287. https:// doi.org/10.2307/1244500.

Tsai YT, Li CY, Cien LT, Lee TM, Wei CI, Hwnag DF. 2006. Histamine contents of fermented fish products in Taiwan and isolation of histamineforming bacteria. Food Chemistry 98(1): 64-70. https://doi.org/10.1016/j. foodchem.2005.04.036.

Venter K, Merwe DV, Beer HD, Kempen E, Bosman M. 2011. Consumers' perceptions of food packaging: an explatory investigation in Potchefstroom, South Africa. International Journal of Consumer Studies 35:273-281. https://doi.org/10.1111/ j.1470-6431.2010.00936.x.

Verbeke W, Brunso K. 2006. Consumer awareness, perceptions and behaviour toward farmes versus wild fish. Food Quality and Preference 17(6):453-467.https://doi.org/10.1016/j. foodqual.2005.05.010.

Verbeke W, Ward R. 2006. Consumer interest in information cues denoting quality, tracebility and origin: an application of orered probit models to beef labels. Food Quality and Preference 27(6): 453-467. 
Verma R, Upadhyaya A. 2014. Effect of age on consumer preference for local grocery stores. SVIM E-Journal of Applied Management II: 48-53.

Wandel M. 1997. Food labelling from a consumer perspective. BritishFoodJournal99(6):212-220. https://doi.org/10.1108/00070709710181559.

Webster C, Reiss M. 2001. Do established antecedents of purchase decision-making power apply to contemporary couples? Psychology \& Marketing 18(9): 951-972. https://doi.org/10.1002/ mar. 1037.

Wedel M, Kamakura W. 2000. Market Segmentation: Conseptual and Methodological Foundations. Dordrecht: Kluwer Academic. https://doi. org/10.1007/978-1-4615-4651-1.

Westlund L. 2005. Future prospects for fish and fishery products. Forecasting fish consumption and demand analysis: a literature review. Fisheries Circular No. 972/5. Rome, Italy: FAO.
Wijaya BS. 2013. Dimensions of brand image: a conceptual review from the perspective of brand communiaction. European Journal of Busiess and Management 5(3): 55-65.

Wills JM, Schmidt DB, Pillo-Blocka F, Cairns G. 2009. Exploring global consumer attitudes toward nutrition information on food labels. Nutrition Reviews 67(5): S102-S106. https://doi. org/10.1111/j.1753-4887.2009.00170.x.

Wongleedee K. 2015. Marketing mix and purchasing behavior for community products at local markets. Procedia - Social and Behavioral Sciences 197: 2080-2085. https://doi.org/10.1016/j. sbspro.2015.07.323.

Zeithaml V. 1988. Consumer perception, price, quality, and value: a means end model and aynthesis of evidence. Journal of Marketing 3: 2-22. https:// doi.org/10.2307/1251446.

Zekiri J. 2015. The role and impact of the packaging effect on consumer buying behaviour. ECOFORUM 4(1): 232-240 